\title{
Vertical differentiation of pedogenic iron forms - a key of hydromorphic soil profile development
}

\author{
Marianna RINGER ${ }^{1}$, Gergely JAKAB ${ }^{1,2}$, Péter SIPOS 3 , Máté SZABÓ, \\ Kata HORVÁTH-SZABÓ ${ }^{1}$, KatAlin PERÉNYI ${ }^{4}$ and ZoltáN SZALAI ${ }^{1,2}$
}

\begin{abstract}
This paper focuses on the vertical distribution and characterisation of pedogenic iron forms in a GleysolHistosol transect developed in a marshy area in the Danube-Tisza Interfluve, Hungary. Four soil profiles were investigated along a series of increasing waterlogging and spatial and temporal patterns of hydromorphic pedofeatures (characteristics of pedogenic iron forms) were recorded. Frequent and wide-range redox potential (Eh) changes caused the emergence of many types of redoximorphic iron features, including mottles, plaques and nodules. The forms of these features depended on the micro-environments determined by the vertical position in the soil profile and the presence of plant roots. The greatest iron enrichment occurred in the zone of most intensive and widest-range redox fluctuations. Increasing water saturation resulted the extension of gleyic pattern due to the existence of permanent reduction. Most of the features also showed annual variations during the varying periods of water saturation and aeration.
\end{abstract}

Keywords: pedogenic iron forms, redoximorphic pedofeatures, hydric soil formation, gleysation, soil colour

Received September 2021, accepted November 2021.

\section{Introduction}

The development of hydric soils is determined by longer or shorter periods of water saturation. As water is the weathering reactive agent as well as the transporting phase of solutes and colloidal components through soil profiles (CHADwick, O.A. and Chorover, J. 2001), waterlogging plays an intensifying role in the development of hydric soils (LiN, H. et al. 2012). As a result, weathering of primary minerals of the parent material and, thereafter, the precipitation of pedogenic iron minerals take place in environmental time scale and are often supported by min- eral-rich groundwater in the case of hydric soils (Thompson, C.A. et al. 1992; Amon, J.P. et al. 2002; KАтsiкороulos, D. et al. 2009).

The altering of water-saturated (reductive) and aerated (oxidative) periods provides a platform for specific soil-forming processes that produce redoximorphic features in the soil profiles (CoRNELL, R.M. and Schwertmann, U. 2003). Ever-changing Eh (redox potential) promotes the transformation and redistribution of redox-sensitive soil components, with particular regard to iron compounds. Permanently water-saturated soil horizons exhibit strongly reducing conditions which results the absence of iron

\footnotetext{
${ }^{1}$ Geographical Institute, Research Centre for Astronomy and Earth Sciences, Budaörsi út 45. H-1112 Budapest, Hungary. Correspondent author's e-mail: ringer.marianna@csfk.org

${ }^{2}$ ELTE Eötvös Loránd University, Institute of Geography and Earth Sciences, Department of Environmental and Landscape Geography, Pázmány Péter sétány 1/c. H-1117 Budapest, Hungary.

${ }^{3}$ Institute for Geological and Geochemical Research, Research Centre for Astronomy and Earth Sciences, Budaörsi út 45. H-1112 Budapest, Hungary.

${ }^{4}$ ELTE Eötvös Loránd University, Department of Analytical Chemistry, Pázmány Péter sétány 1/a. H-1117 Budapest, Hungary.
} 
(light grey colour) or the presence of ferrous components (green colour). Water table fluctuations lead to redox changes followed by the appearance of reddish to yellowish brown colour in the soil profile due to the enrichment of different Fe oxy-hydroxides (Golden, D.C. et al. 1997; Cornu, S. et al. 2009; LindBo, D.L. et al. 2010). Newly formed iron minerals can appear as mottles, cutans or nodules. The first signs of these redoximorphic features can develop in a few years or less (Amon, J.P. et al. 2005). The spatial and temporal distribution of iron forms along the soil profiles is determined mainly by the intensity of waterlogging and redox fluctuations (Imbellone, P.A. et al. 2009).

This paper focuses on the vertical distribution and characterisation of iron compounds in a Gleysol-Histosol transect developed in a marshy area in the Danube-Tisza Interfluve, Hungary.

Our aims are to (1) reveal the forms and distribution patterns of pedogenic Fe compounds found in the studied hydric soil profiles, (2) find the relationship between the specific redoximorphic features and the degree of waterlogging, and, (3) detect how these Fe compounds indicate the soil environment in which they were formed.

\section{Materials and methods}

\section{Study area}

The study area is located in the DanubeTisza Interfluve, Central Hungary (N $47^{\circ} 12^{\prime}$ $23,37^{\prime \prime}$ E $\left.19^{\circ} 40^{\prime} 54,87^{\prime \prime}\right)$. The nearly flat plain is covered by sedimentary, coarse calcareous quartz sands of Pleistocene age (DövénYI, Z. 2010; Kalmár, J. et al. 2012). The study area lies on an approx. 8 ha marshy meadow in the former floodplain of the stream Gerje.

The primary surface consisted of a succession of low ridges of sand dunes and shallow troughs along the stream. Peat formation took place in the depressions. A layer of calcareous sand material from the adjacent hills was deposited on the surface via an extreme- ly heavy flash flood event in 1963 (SURÁNYI, D. 1965 - L. Pultzer pers. commun.). Since then, there has been no sediment deposition again. As part of waste-water management in the 1970s (BARANYAI, Zs. et al. 2014) the Gerje stream bed was settled and regularly dredged. As a result, the groundwater level has dropped to an average of approx. $30 \mathrm{~cm}$ below the surface but still shows a widerange seasonal fluctuation. The meadow is flooded on average 5-9 months of the year. The topsoil is almost permanently water-saturated, exceeding field capacity. The groundwater level is often above the soil surface in the early spring and gradually decreases during the summer, reaching its minimum in the late autumn and winter.

In the present work, we investigated four hydromorphic soil profiles (M1-M4) assigned along a transect of increasing duration of water saturation (Figure 1). M1 profile is the least affected by water. The upper 20 $\mathrm{cm}$ is always aerated but also moist due to capillary rise. M4 profile is constantly under water. M2 and M3 profiles form a transition between the former two, with altering water cover, water saturation and aeration, following the annual fluctuations of the groundwater level. The vegetation pattern follows hydric characteristics, with alternating wet meadow, sedge and reed along the transect.

Samples were collected from each diagnostic soil horizon. Where possible, nodules and Fe-rich root channel infillings were collected as well. Samples for laboratory measurements were taken by Edelman auger, immediately put into Falcon type high purity polyethylene tubes and stored at $4{ }^{\circ} \mathrm{C}$ until being measured. Field studies were planned and performed based on the inscriptions of the World Reference Base for Soil Resources - WRB (Schoeneberger, P.J. 2012; IUSS Working Group WRB, 2014).

\section{Field observations}

Distribution of carbonate, $\mathrm{Fe}^{2+}$ and $\mathrm{Mn}^{2+}$ content was detected via simple chemical tests by 


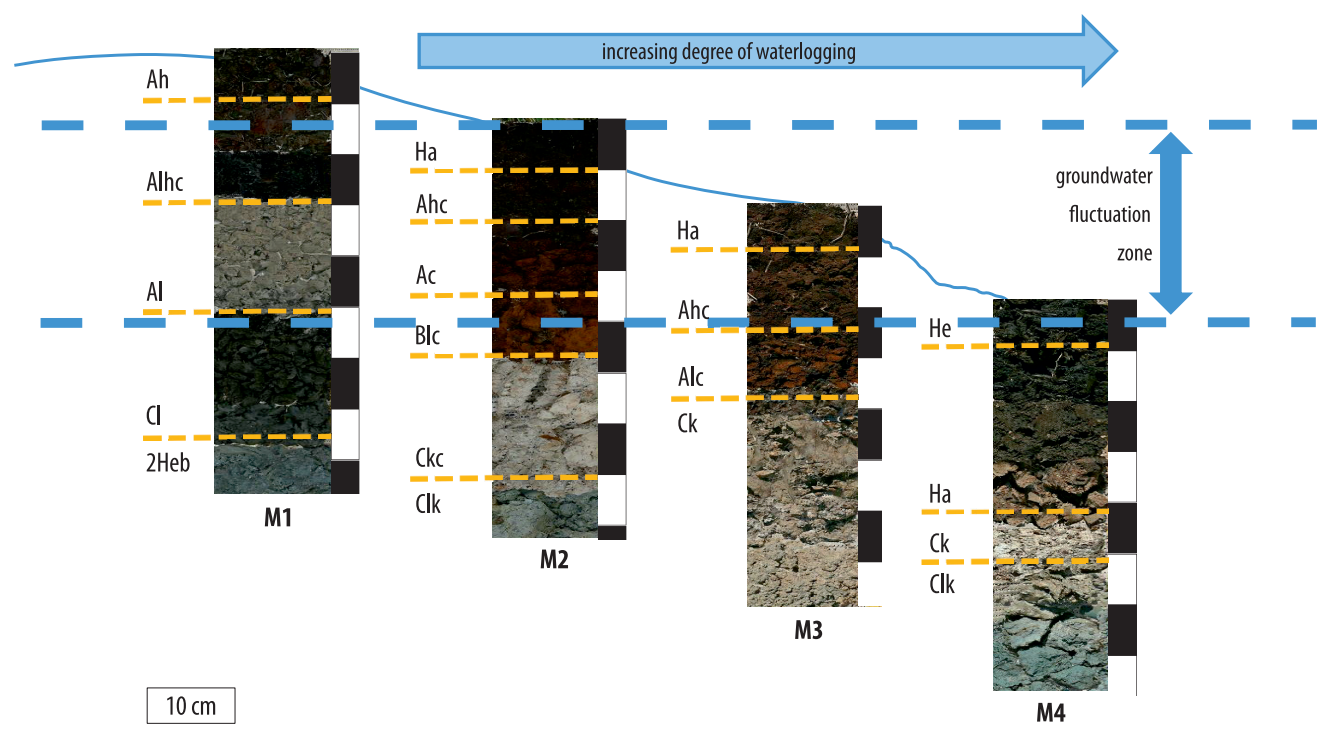

Fig. 1. Position of the studied soil profiles along the transect of different depths of waterlogging

10 percent hydrochloric acid, $\alpha, \alpha$-dipyridyl dye (Childs, C.W. 1981), and 10 percent hydrogen peroxide, respectively. The presence of Fe(III) compounds was inferred from their characteristic reddish-brown hue. Soil colour was determined by Munsell colour chart.

Redox potential (Eh) and $\mathrm{pH}$ in the rooting zone (in 20 and $40 \mathrm{~cm}$ depth) and in the permanently water-saturated zone (in 100-120 cm depth) were being monitored in the area during the vegetation period in earlier studies (SzalaI, Z. et al. 2010, 2012, 2021).

\section{Morphological study}

Stereomicroscopic studies were carried out and photos of redoximorphic features were taken by ToupLite software. Spatial distribution of the major chemical elements of the Fe nodules was studied by point analyses by a JEOL Superprobe JCXA-733-type electron micro-probe equipped with an INCA Energy 200 energydispersive spectrometer. An acceleration voltage of $20 \mathrm{kV}$, a probe current of $3 \mathrm{nA}$, and a count time between 10 and $60 \mathrm{~s}$ were used for the analyses. The diameter of the electron beam used for the micro-chemical analyses was $1 \mu \mathrm{m}$. The fabric of the Fe nodules was studied by analysing the backscattered electron images of the polished surfaces.

\section{Analytical overview}

For the measurements, samples were air-dried, cleaned from plant residues and mollusc shells and sieved through $2 \mathrm{~mm}$ sieve (VAN REeUwiJK, L.P. 2002). The total Ca (and Mg) carbonate content was determined using Scheibler's gas volumetric method (RoweL, D.L. 1994).

Selective chemical extractions were applied to determine the free $\mathrm{Fe}$ and $\mathrm{Mn}$ contents. Free (CBD) Fe and Mn phase was extracted by dithionite-citrate-bicarbonate solution according to HoLMGREN's procedure (Holmgren, G.G.S. 1967). The samples and reagents were placed in centrifuge tubes, were shaken for 16 hours and, centrifuged at a speed of 4,000 rpm for 20 minutes. The residues of the extractions were twice again washed with the reagents due to the great 
amount of extractable Fe present in the samples. The solutions were diluted and then dissolved Fe and Mn content was measured by atomic absorption spectroscopy, using Perkin Elmer AS300 Fl-AAS, at $248.3 \mathrm{~nm}$ (for $\mathrm{Fe}$ ) and $279.5 \mathrm{~nm}$ (for $\mathrm{Mn}$ ) wavelength.

\section{Results}

Toposequence of the hydromorphic soil profiles

The toposequence of soil profiles toward the increasing degree of waterlogging is Calcaric Mollic Gleysol (Endoarenic, Epiloamic, Hyperhumic), Calcaric Calcic Histic Gleysol (Endoarenic, Epiloamic), Calcaric Histic Gleysol (Endoarenic, Epiloamic), and Fibric Eutric Histosol (Calcaric, Mineralic), referred to as M1, M2, M3 and M4, respectively, in the text.

The uppermost $10 \mathrm{~cm}$ of M1 formed a hyperhumic mollic horizon (Table 1), followed by the Alc horizon $(10-35 \mathrm{~cm})$ also characterised by SOM (soil organic matter) and Fe oxyhydroxide enrichment (> 50\% mottles). The $\mathrm{C}$ horizon was slightly mottled. The depth of the buried Histosol (H2eb) was about $80 \mathrm{~cm}$.

The uppermost $10 \mathrm{~cm}$ of M2 was a histic horizon (Ha). The uppermost mineral horizon (Alhc) of M2 (10-35 cm) was characterised by SOM enrichment, a clay loam/silty clay texture, and Fe oxy-hydroxide accumulation. A reddish colour dominated the soil matrix between $10 \mathrm{~cm}$ and $45 \mathrm{~cm}$ due to a high amount of free Fe oxy-hydroxide minerals. Fe oxy-hydroxide masses, Fe mottles, and Fe plaques (rusty root channels) appeared in the upper $20 \mathrm{~cm}$. While mottles and Fe plaques were dominant in the Ah horizons, the amount of Fe nodules increased to a depth of $45 \mathrm{~cm}$. Root density (with dominant species being Carex riparia and Carex vulpina) was the highest between $35-45 \mathrm{~cm}$. A zone of fine-grain carbonate accumulation was found at the depth of $45-70 \mathrm{~cm}$, containing numerous irregularly shaped carbonate nodules of varying sizes. The gleyic pattern appeared below $70 \mathrm{~cm}$ in a sandy-loam-textured horizon.
The uppermost $10 \mathrm{~cm}$ of the M3 formed a histic horizon (Ha) followed by two organicrich A horizons (Ahc and Ac) with continuously decreasing SOM content and common Fe plaques and many coarse black and reddish mottles. The extent and distribution of red and black mottles could make it impossible to determine the colour of the soil matrix. Below $50 \mathrm{~cm}$ powdery lime enrichment was present $(\mathrm{Ckc})$ with few fine Fe mottles.

The uppermost $40 \mathrm{~cm}$ of the M4 profile was extremely rich in SOM, arranged in two histic horizons (He and Ha). Below $40 \mathrm{~cm}$ disperse powdery lime was present $(\mathrm{Ckc})$ with Gleyic pattern starting from $50 \mathrm{~cm}(\mathrm{Clk})$.

\section{Field observations}

The $\alpha, \alpha$-dipyridyl dye and hydrogen peroxide tests showed permanently positive results in the topsoils (Table 2). The amount of Fe(II) increased with the duration of water saturation. With the lowering of the groundwater table, the abundance of reduced phases decreased.

Annual changes of soil colour could be observed (Table 3). The reddish colour appeared and became dominant during the summer via extended precipitation of Fe oxy-hydroxides in the zone of decreasing groundwater level (M1M3). In some cases, soil colour in this depth of M1 and M2 was indeterminate because of the great variety of different hues (Photo 1). In the upper $35 \mathrm{~cm}$ of M1 profile darkening was observed. Gleyic pattern appeared in many different hues in the permanently water-saturated zone. In profile M4 reddish hue was missing, most likely due to mostly reduced Fe forms.

\section{Morphology of iron plaques, coatings and nodules}

Fe plaques and Fe nodules often occurred in a combined way (Photo 2) in the upper 20 $\mathrm{cm}$ of the studied soil profiles. Single Fe nodules found in 35-45 cm depth were built up of mineral particles of the soil matrix stuck together by finer Fe precipitations. 


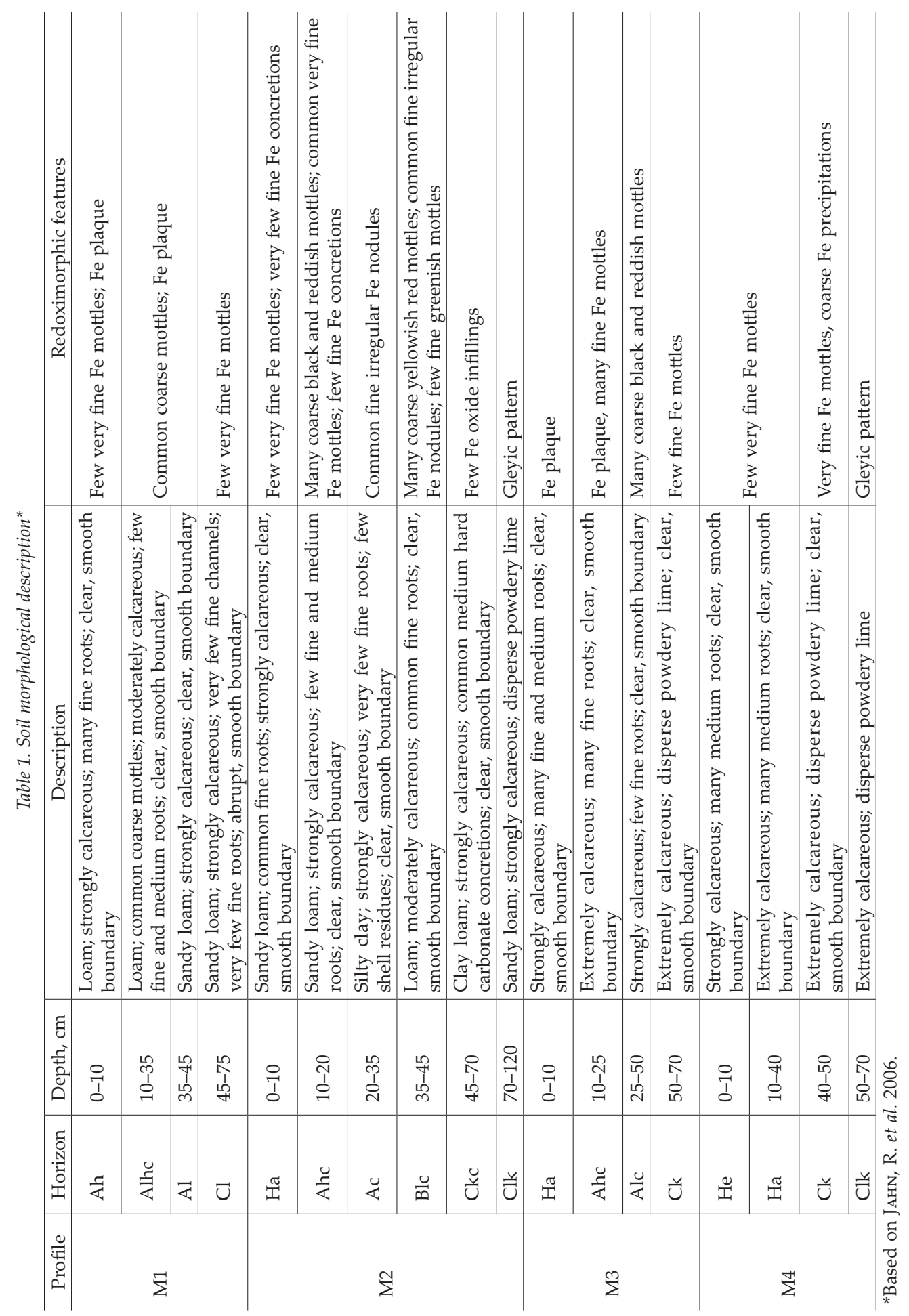


Table 2. Seasonal changes of $\mathrm{Fe}(\mathrm{II})$ and $\mathrm{Mn}$ (II) content of the soil horizons during the year 2013, detected by $\alpha, \alpha$-dipyridyl dye and hydrogen peroxide, respectively

\begin{tabular}{|c|c|c|c|c|c|c|c|c|c|c|c|c|}
\hline \multirow{2}{*}{$\begin{array}{c}\text { Soil } \\
\text { profile }\end{array}$} & \multirow{2}{*}{ Horizon } & \multirow{2}{*}{$\begin{array}{l}\text { Depth, } \\
\text { cm }\end{array}$} & \multicolumn{2}{|c|}{ May } & \multicolumn{2}{|c|}{ July } & \multicolumn{2}{|c|}{ August } & \multicolumn{2}{|c|}{ September } & \multicolumn{2}{|c|}{ October } \\
\hline & & & $\mathrm{Fe}$ & Mn & $\mathrm{Fe}$ & $\mathrm{Mn}$ & $\mathrm{Fe}$ & Mn & $\mathrm{Fe}$ & Mn & $\mathrm{Fe}$ & Mn \\
\hline \multirow{5}{*}{ M1 } & $\mathrm{Ah}$ & $0-10$ & $* * *$ & \multirow{5}{*}{ nd } & $*$ & $* *$ & * & $* * *$ & * & * & $* *$ & $*$ \\
\hline & Alhc & $10-35$ & $* *$ & & * & $*$ & * & * & - & * & $* *$ & $*$ \\
\hline & $\mathrm{Al}$ & $35-45$ & $* * *$ & & $* *$ & * & $* *$ & - & - & - & $* *$ & - \\
\hline & $\mathrm{Cl}$ & $45-75$ & $*$ & & $*$ & * & - & $*$ & - & - & $*$ & - \\
\hline & $2 \mathrm{Heb}$ & $75-100$ & $* * *$ & & $* *$ & - & $* * *$ & $* *$ & ** & - & ** & - \\
\hline \multirow{6}{*}{ M2 } & $\mathrm{Ha}$ & $0-10$ & $* * *$ & \multirow{6}{*}{ nd } & $* * *$ & ** & $* * *$ & $* * *$ & nd & nd & $* * *$ & $* *$ \\
\hline & Ahc & $10-20$ & $*$ & & $*$ & $* * *$ & * & $* * *$ & $*$ & $* *$ & - & $*$ \\
\hline & Ac & $20-35$ & $* *$ & & * & $* *$ & * & $* * *$ & - & $*$ & - & $*$ \\
\hline & Blc & $35-45$ & $* *$ & & * & * & - & $* * *$ & - & $* *$ & - & - \\
\hline & Ckc & $45-70$ & $* * *$ & & $*$ & - & - & $* *$ & ** & * & $* *$ & - \\
\hline & $\mathrm{Clk}$ & $70-120$ & $* * *$ & & $* *$ & * & $* *$ & $*$ & $* * *$ & $*$ & $* * *$ & - \\
\hline \multirow{4}{*}{ M3 } & $\mathrm{Ha}$ & $0-10$ & \multirow{4}{*}{ nd } & \multirow{4}{*}{ nd } & $* * *$ & * & * & $* *$ & $* * *$ & $* * *$ & $* * *$ & ** \\
\hline & Ahc & $10-25$ & & & $*$ & * & - & $* *$ & - & $* *$ & - & * \\
\hline & Alc & $25-50$ & & & $*$ & $*$ & - & $* *$ & - & $* * *$ & - & * \\
\hline & $\mathrm{Ck}$ & $50-70$ & & & $* * * *$ & - & $* *$ & - & $* *$ & $*$ & $* *$ & $*$ \\
\hline \multirow{4}{*}{ M4 } & $\mathrm{He}$ & $0-10$ & \multirow{4}{*}{ nd } & \multirow{4}{*}{ nd } & $* * * *$ & * & \multirow{4}{*}{$* * *$} & $* *$ & \multirow{4}{*}{$* * *$} & $*$ & $* * *$ & $*$ \\
\hline & $\mathrm{Ha}$ & $10-40$ & & & $* * * *$ & * & & $* * *$ & & $* *$ & - & $*$ \\
\hline & $\mathrm{Ck}$ & $40-50$ & & & $* *$ & - & & $*$ & & - & - & - \\
\hline & Clk & $50-70$ & & & $* * *$ & - & & nd & & - & * & - \\
\hline
\end{tabular}

Notes: ${ }^{* * *}$ strong, ${ }^{* *}$ medium, ${ }^{*}$ slight reaction; - : no reaction; nd: no data.

Fe and Mn distribution of Fe plaques and Fe nodules did not show a clear pattern (Figure 2) and a regular structure could not be detected.

The structure of different kinds of Fe precipitations seemed to be different depending on their location. Fe plaques were built up of finer Fe precipitants of a rather homogenous distribution. Their colour showed differences: a darker reddish hue was located by the plant roots and a lighter orange hue was observed at a distance (see Photo 2).

\section{Chemistry}

Free Fe and Mn distribution showed a notable pattern in the soil profiles (Table 4). Fe and Mn enrichment was observed in the topsoils with SOM accumulation and they reached the maximum amount in the zone of groundwater level oscillation. In the studied soils (M1-M3) Fe amounts of the intensive Eh changes increased with increasing degree of waterlogging, while Mn reached its maximum in the buried H2eb and Alhc horizon of M1 and Ahc horizon of M2. Permanently reduced horizons were low in free Fe and $\mathrm{Mn}$. The molar ratio of Fe and Mn was imbalanced by the great amount of Fe.

Different amounts of $\mathrm{CaCO}_{3}$ was detected in all horizons except for the H2eb in M1. Permanently water-saturated horizons contained great carbonate accumulation in the form of powdery lime and nodules of different sizes. $\mathrm{pH}$ varied between 7.2 and 8.1 showing maxima under $50 \mathrm{~cm}$ of M3 and M4.

\section{Discussion}

Redoximorphic features were represented by different forms of Fe and Mn compounds 
Table 3. Colour of the bulk soil and its annual changes based on the Munsell colour chart

\begin{tabular}{|c|c|c|c|c|c|c|}
\hline \multirow{2}{*}{ Profile } & \multirow{2}{*}{ Horizon } & \multirow{2}{*}{$\begin{array}{l}\text { Depth, } \\
\mathrm{cm}\end{array}$} & \multicolumn{4}{|c|}{ Munsell colour (moist) } \\
\hline & & & May & August & September & October \\
\hline \multirow{5}{*}{ M1 } & $\mathrm{Ah}$ & $0-10$ & 10YR 2/1 & 7.5YR 2.5/2 & 10YR 2/2 & 7.5YR 2.5/1 \\
\hline & Alhc & $10-35$ & $\begin{array}{l}\text { 10YR } 2 / 2 \\
7.5 \text { YR 5/8 }\end{array}$ & $7.5 Y R$ 5/8 & $2.5 Y 2.5 / 1$ & 7.5YR 2.5/1 \\
\hline & $\mathrm{Al}$ & $35-45$ & 7.5YR 2.5/1 & indet. & indet. & N 2.5/ \\
\hline & $\mathrm{Cl}$ & $45-75$ & $2.5 Y R 4 / 2$ & $2.5 Y R 5 / 3$ & $2.5 Y 5 / 2$ & $2.5 Y 5 / 3$ \\
\hline & $2 \mathrm{Heb}$ & 75-100 & $\begin{array}{c}10 \mathrm{YR} 2 / 1 \\
2.5 \mathrm{Y} 4 / 2\end{array}$ & 10YR 2/1 & $5 Y 2.5 / 1$ & 10YR 2/1 \\
\hline \multirow{7}{*}{ M2 } & $\mathrm{Ha}$ & $0-10$ & $7.5 Y R 3 / 2$ & 10YR 2/1 & 7.5YR $2.5 / 2$ & 10YR 2/2 \\
\hline & Ahc & $10-20$ & 7.5YR 3/4 & 7.5YR 3/2 & 7.5YR 3/2 & 10YR 3/2 \\
\hline & $\Delta c$ & $20-35$ & 7.5YR 3/4 & & 7.5YR 4/6 & 10YR 2/2 \\
\hline & Ac & $20-35$ & 7.5YR 5/6 & indet. & 7.5YR 5/8 & 7.5YR 5/8 \\
\hline & Blc & $35-45$ & 7.5YR 5/6 & indet. & 10YR $8 / 2$ & 10YR 4/1 \\
\hline & Ckc & $45-70$ & 10YR 7/1 & 10YR 7/1 & 10YR 7/2 & 10YR $8 / 3$ \\
\hline & $\mathrm{Clk}$ & $70-120$ & $10 G Y 5 / 1$ & $5 G 7 / 2$ & 5 GY $6 / 1$ & 10GY 5/1 \\
\hline \multirow{5}{*}{ M3 } & $\mathrm{Ha}$ & $0-10$ & & $5 Y 2.5 / 1$ & 10YR $2 / 2$ & 10YR 2/2 \\
\hline & Ahc & $10-25$ & 10YR 3/4 & $7.5 Y 3 / 3$ & 7.5YR 3/3 & 10YR 3/2 \\
\hline & ع & $25-50$ & 10 YR $3 / 3$ & $75 \mathrm{YR} 5 / 8$ & 7.5YR 4/4 & \\
\hline & & & & 7.5Yर 5/8 & 7.5YR 5/8 & 10YR 4/2 \\
\hline & $\mathrm{Ck}$ & $50-70$ & $10 Y 8 / 1$ & $2.5 Y 6 / 2$ & $2.5 Y 7 / 2$ & $2.5 Y 6 / 2$ \\
\hline \multirow{4}{*}{ M4 } & $\mathrm{He}$ & $0-10$ & nd & 10YR 2/1 & $2.5 Y 2.5 / 1$ & $2.5 Y 2.5 / 1$ \\
\hline & На & $10-40$ & nd & 10YR 2/2 & $7.5 Y 5 / 2$ & $2.5 Y 2.5 / 1$ \\
\hline & $\mathrm{Ck}$ & $40-50$ & nd & $2.5 Y 7 / 2$ & $5 G Y 7 / 1$ & 10YR 5/2 \\
\hline & Clk & $50-70$ & nd & nd & $5 G 5 / 2$ & $2.5 Y 7 / 1$ \\
\hline
\end{tabular}

Notes: indet. $=$ indeterminate, $\mathrm{nd}=$ no data.

in the studied soil profiles (Table 5). The distribution of these features showed a vertical and a horizontal pattern following the main characteristics of groundwater fluctuations. In this environment, the conditions often resulted $\mathrm{Fe}(\mathrm{II}) / \mathrm{Fe}(\mathrm{III})$ oxidation state transition, causing Fe enrichment also in micro- and macro-scale.

Fe mottles represented the first signs of hydromorphism and were commonly found in the studied soils. Their prevalence and volume increased with the effect of waterlogging. In some cases (in M1 and M2), soil colour was indeterminate due to multi-colouration. Annual soil colour changes were driven by Eh and the corresponding species and forms of Fe. The effect of Fe oxyhydroxides on soil colour have been extensively investigated and detailed in previous studies (SchwertmanN, U. 1993; Cornell, R.M. and Schwertmann, U. 2003; IbÁÑEZAsensio, S. et al. 2013; Martín-García, J.M. et al. 2016; Cundros, J. et al. 2020; Samus, M.G. et al. 2021). Accordingly, yellowish and reddish hue is due to Fe(III) minerals, such as goethite, lepidocrocite, jarosite and hematite (the first two are typical of hydromorphic soils). Greenish or greyish colour is usually attributed to the presence of Fe(II) compounds under hydric conditions. 

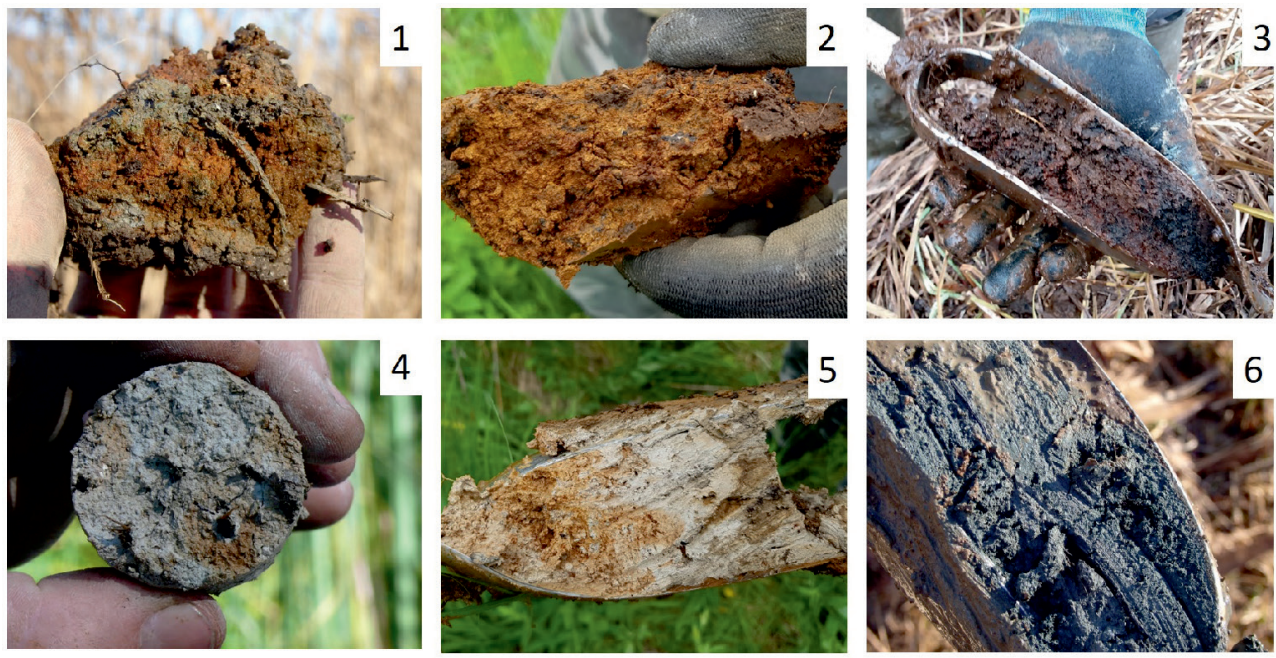

Photo 1. Field photos of collected soil samples: $1=\mathrm{M} 2$ 20-35 cm; $2=\mathrm{M} 2$ 35-45 cm; $3=\mathrm{M} 310-25 \mathrm{~cm} ; 4=\mathrm{M} 2$ $50-70 \mathrm{~cm}$ in May; $5=\mathrm{M} 250-70 \mathrm{~cm}$ in August; $6=\mathrm{M} 450-70 \mathrm{~cm}$.
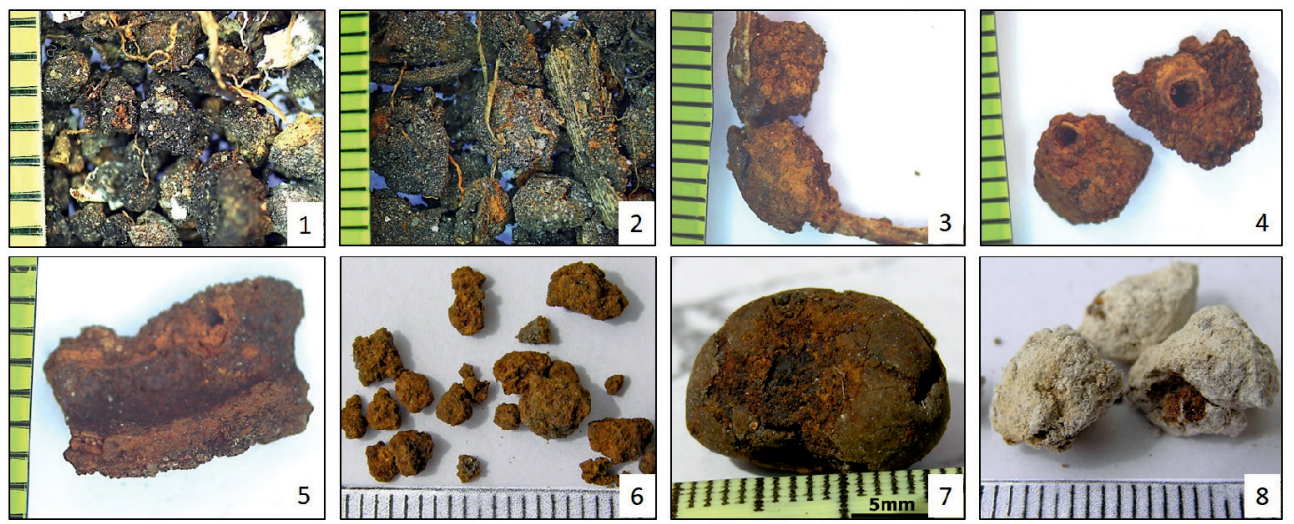

Photo 2. Stereomicroscopic photos of redoximorphic features. $1=\mathrm{M} 3$ topsoil $(0-8 \mathrm{~cm})$ with Fe mottles; $2=\mathrm{M} 4$ topsoil $(0-5 \mathrm{~cm})$ with Fe mottles; 3 and $4=$ combined Fe plaque and Fe nodule from M2 $35-50 \mathrm{~cm} ; 5=$ Fe plaque from M1 22-42 cm; 6 = 2-5 mm Fe nodules from M2 10-25 cm; 7 = $15 \mathrm{~mm}$ Fe nodule from M2 35-45 cm; 8 = carbonate concretions with Fe impregnation from M2 $50-70 \mathrm{~cm}$.

Fe oxy-hydroxide enrichment is often associated to plant root environment, forming Fe plaques. Fe plaques were often combined with Fe nodules, but these formations showed similar fine structures. Dark red-brown colour (located close to the plant roots) referred to short-range ordered fer- rihydrite, while a lighter hue of orange assumed the presence of more crystalline goethite (Driessen, P. et al. 2001).

Waterlogging-induced Fe nodules in the bulk soil of M2 and M3 were built up of mineral particles cemented by Fe precipitation. The irregular shape and the incorporation 

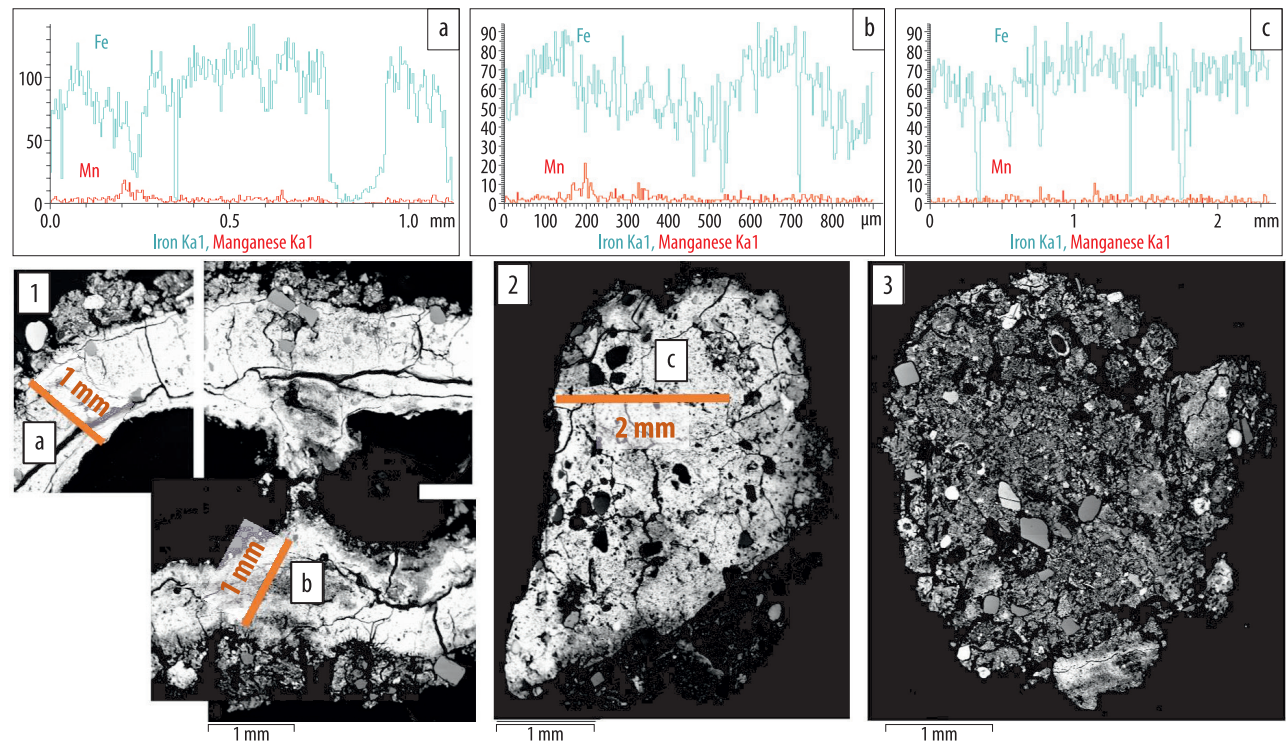

Fig. 2. SEM images of the polished surface of Fe plaque (1) and Fe nodules connected to Fe plaque (2) and standing alone in the bulk soil (3). Orange lines (a, b, c) mark the location of the recorded Fe and Mn K $\alpha$ spectra $(a, b, c)$. The horizontal axes of the spectra are of the same size as the orange lines.

Table 4. Some chemical characteristics of the soil profiles

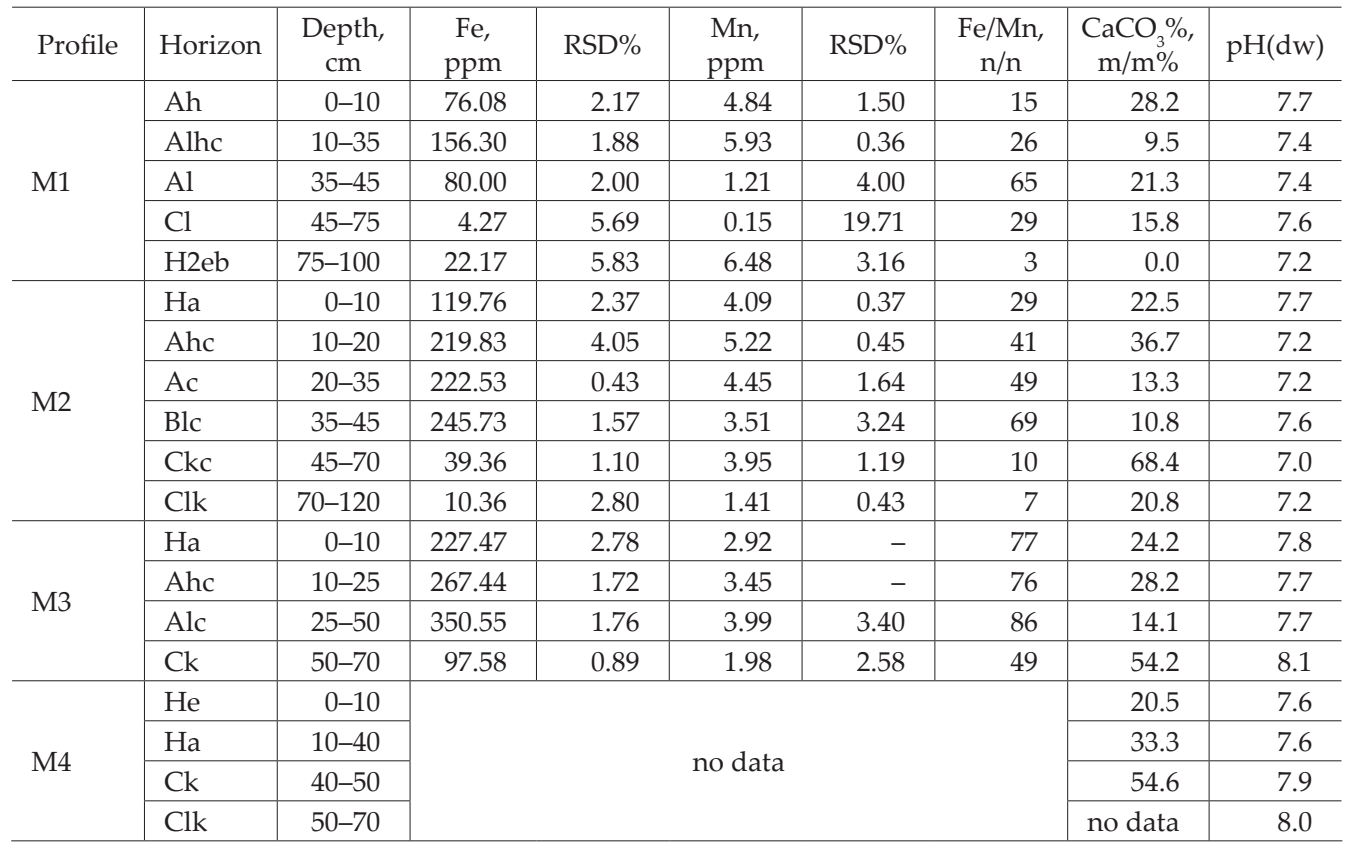


Table 5. Summary of redoximorphic features found and soil environments under hydric conditions

\begin{tabular}{|c|c|c|}
\hline Hydromophy & Redoximorphic features & Environment \\
\hline \multirow{5}{*}{$\begin{array}{l}\text { Increasing duration } \\
\text { of water saturation }\end{array}$} & Fe mottles ${ }^{1}$ & Periodic water saturation \\
\hline & Fe plaques ${ }^{2}$ & Locally varying Eh (root environment) \\
\hline & Fe enrichment, changing colour & $\begin{array}{l}\text { Eh varying around } \mathrm{Fe}(\mathrm{II}) / \mathrm{Fe}(\mathrm{III}) \text { oxidation state } \\
\text { transition }\end{array}$ \\
\hline & Fe nodules ${ }^{3}$ & Periodically changing Eh (fluctuating groundwater) \\
\hline & Gleysation, lack of Fe(III) & Permanently reduced (water-saturated) \\
\hline
\end{tabular}

Definitions: ${ }^{1}$ Mottles $=$ spots or blotches of different colours or shades of colour interspersed with the dominant colour of the soil; ${ }^{2}$ Plaques $=$ films of poorly crystalline Fe oxides deposited on the surface of plant roots; ${ }^{3}$ Nodules $=$ discrete bodies without an internal organisation. Gradual transitions exist with mottles (HANSEL, C.M. et al. 2001; JAHN, R. et al. 2006).

of soil matrix material in these Fe nodules reflect dynamically varying Eh (Sтоор, G. et al. 2010; Sipos, P. et al. 2011; SzEndrei, G. et al. 2012; Gasparatos, D. et al. 2019).

SOM content of the topsoils seemed to result $\mathrm{Fe}(\mathrm{II})$ and Mn enrichment which pointed out the relevance of interactions between $\mathrm{Fe}$, $\mathrm{Mn}$ and organic compounds. Complex forming and co-precipitation of these components may be a significant driver of $\mathrm{Fe}, \mathrm{Mn}$ and carbon redistribution (SODANO, M. et al. 2017; HuAng, X. et al. 2018, 2020; TANgen, B.A. and BAnsal, S. 2020; Kocsis, T. et al. 2020; BI, Y. et al. 2021; PAPP, O. et al. 2021). The co-occurrence of $\mathrm{Fe}(\mathrm{II})$ and $\mathrm{Fe}(\mathrm{III})$ reflects locally and intensively changing conditions.

Gleysation appears below $70 \mathrm{~cm}$ in M2 and $\mathrm{M} 3$, and below $40 \mathrm{~cm}$ in M4 due to the presence of poorly crystalline Fe(II) compounds (so-called green rust / fougérite minerals), which cannot be examined successfully by routine procedures (Bourrié, G. et al. 1999; Feder, F. et al. 2005; Mills, S.J. et al. 2012).

\section{Conclusions}

Redistribution of iron along the soil profile acts as a key process in the development of hydromorphic soils. The first signs of these alterations can occur in a few years. The aim of this paper was to characterise the redoximorphic features of pedogenic iron forms in four hydromorphic soil profiles along a sequence of increasing duration of water saturation. Fluctuating groundwater table causes changing Eh environments resulting special conditions for the formation of redoximorphic features, such as iron mottles and nodules. Changes in soil colour and iron forms can be observed in a few months and may have an annual pattern following the groundwater fluctuations. Plant roots control Eh locally resulting the formation of special features similar to the ones originated from waterlogging. The longer the waterlogging persists in the given depth of the soil profile, the more reductomorphic features appear. Gleyic pattern was linked to permanently reductive conditions, although Fe could also be reduced by $\mathrm{SOM}$ in topsoil environments. Increasing degree of waterlogging resulted the extension of gleysation. Spatial and temporal patterns of water saturation established the hydromorphic properties of hydromorphic soil profiles. Groundwater level fluctuations followed by Eh oscillations may cause changes in soil colour due to iron oxidation state changes and mineralogical alterations. Seasonally changing soil colour and redoximorphic iron features may also be of interest for soil description and soil classification, giving a different result depending on the date of the investigation.

Acknowledgement: The research was supported by the European Union and the State of Hungary and Hungarian Scientific Research Fund (K100180 for Z. SzALAI, K100181 for T. NÉMETH, and K123953 for $G$. JAKAB). The research was supported by the Hungarian Academy of Sciences (NANOMIN pro- 
ject, KEP 08/2018, ELKH 01/2020). TEM studies were performed at the electron microscopy laboratory of the University of Pannonia, established using grant no. GINOP-2.3.3-15-2016-0009 from the European Structural and Investments Funds and the Hungarian Government. The authors thank Lénárd Pultzer landowner, and József Török, mayor of Ceglédbercel for granting of the study area.

\section{REFERENCES}

Amon, J.P., Thompson, C.A., Carpenter, Q.J. and MineR, J. 2002. Temperate zone fens of the glaciated Midwestern USA. Wetlands 22. (2): 301-317.

Amon, J.P., Jacobson, C.S. and Shelley, M.L. 2005. Construction of fens with and without hydric soils. Ecological Engineering 24. (4): 341-357.

Baranyai, Zs., Schrett, A., Vidra, T., Vincze, T., Kun, A. and Szalkay, J. 2014. A HUDI20021 Gerje mente kiemelt jelentöségü természetmegőrzési terület fenntartási terve (Management plan for the HUDI20021 Gerje mente special area of conservation). Natura 2000. Budapest, Duna-Ipoly Nemzeti Park.

BI, Y., KuzYakov, Y., CaI, S. and Zhao, X. 2021. Accumulation of organic compounds in paddy soils after biochar application is controlled by iron hydroxides. Science of the Total Environment 764. 144300.

Bourrié, G., Troland, F., GÉnin, J.-M.R., JafFrezic, A., Maítre, V. and Abdelmoula, M. 1999. Iron control by equilibria between hydroxy-Green Rusts and solutions in hydromorphic soils. Geochimica et Cosmochimica Acta 63. 3417-3427.

Chadwick, O.A. and Chorover, J. 2001. The chemistry of pedogenic thresholds. Geoderma 100. (3-4): 321-353.

Childs, C.W. 1981. Field tests for ferrous iron and ferric-organic complexes (on exchange sites or in water-soluble forms) in soils. Soil Research 19. (2): 175-180.

Cornell, R.M. and Schwertmann, U. 2003. The Iron Oxides: Structure, Properties, Reactions, Occurrences and Uses. $2^{\text {nd }}$ edition. Weinheim, Wiley-VHC.

Cornu, S., Cattle, J.A., Samoü̈lian, A., Laveuf, C., Guilherme, L.R.G. and Alberic, P. 2009. Impact of redox cycles on manganese, iron, cobalt, and lead in nodules. Soil Science Society of America Journal 73. (4): 1231-1241.

Cuadros, J., Sánchez-Marañón, M., Mavris, C., Fiore, S., Bishop, J.L. and Melgosa, M. 2020. Colour analysis and detection of Fe minerals in multi-mineral mixtures from acid-alteration environments. Applied Clay Science 193. 105677.

DövénYI, Z. (ed.) 2010. Magyarország Kistájainak Katasztere (Inventory of microregions in Hungary). Budapest, MTA Földrajztudományi Kutatóintézet.
Driessen, P., Deckers, J. and Spaargaren, O. (eds.) 2001. Lecture Notes on the Major Soils of the World. Rome, FAO.

Feder, F., Troland, F., Klingelhöfel, G. and Bourrié, G. 2005. In situ Mössbauer spectroscopy: Evidence for green rust (fougérite) in a gleysol and its mineralogical transformations with time and depth. Geochimica et Cosmochimica Acta 69. 4463-4483.

Gasparatos, D., Massas, I. and Godelitsas, A. 2019. $\mathrm{Fe}-\mathrm{Mn}$ concretions and nodules formation in redoximorphic soils and their role on soil phosphorus dynamics: Current knowledge and gaps. Catena 182. 104106.

Golden, D.C., Turner, F.T., Sittertz-Bhatkar, H. and Dixon, J.B. 1997. Seasonally precipitated iron oxides in a vertisol of southeast Texas. Soil Science Society of America Journal 61. (3): 958-964.

Hansel, C.M., Fendorf, S., Sutton, S. and Newville, M. 2001. Characterisation of Fe plaque and associated metals on the roots of mine-waste impacted aquatic plants. Environmental Science \& Technology 35. (19): 3863-3868.

HolmgReN, G.G.S. 1967. A rapid citrate-dithionite extractable iron procedure. Soil Science Society of America Journal 31. 210-211.

Huang, X., Tang, H., Kang, W., Yu, G., Ran, W., Hong, J. and SHEN, Q. 2018. Redox interface-associated organo-mineral interactions: A mechanism for C sequestration under a rice-wheat cropping system. Soil Biology and Biochemistry 120. 12-23.

Huang, X., Kang, W., Guo, J., Wang, L., Tang, H., Li, T., Yu, G., Ran, W., Hong, J. and Shen, Q. 2020. Highly reactive nanomineral assembly in soil colloids: Implications for paddy soil carbon storage. Science of the Total Environment 703. 134728.

Ibáñez-Asensio, S., Marques-Mateu, A., MorenoRAmón, H. and BaLAsch, S. 2013. Statistical relationships between soil colour and soil attributes in semiarid areas. Biosystems Engineering 116. (2): 120-129.

Imbellone, P.A., Guichon, B.A. and Giménez, J.E. 2009. Hydromorphic soils of the Rio de la Plata coastal plain, Argentina. Latin American Journal of Sedimentology and Basin Analysis 16. (1): 3-18.

IUSS Working Group WRB, 2015. World Reference Base for Soil Resources 2014. Update 2015 - international soil classification system for naming soils and creating legends for soil maps. World Soil Resources Reports 106. Global Soil Partnership, International Union of Soil Sciences, and Food and Agriculture Organization of the United Nations. Rome, FAO.

Jahn, R., Blume, H.P., Asio, V.B., Spaargaren, O. and SchaD, P. 2006. Guidelines for Soil Description. $4^{\text {th }}$ edition. Rome, FAO.

Katsikopoulos, D., Ferdández-GonzÁlez, Á. and Prieto, M. 2009. Precipitation and mixing properties of the "disordered" (Mn, Ca)CO3 solid solution. Geochimica et Cosmochimica Acta 73. 6147-6161. 
Kalmár, J., Kuti, L. and Pocsai, T. 2012. A ceglédberceli útbevágás kvarter üledékeinek ásványtani, üledékföldtani és őskörnyezeti vizsgálata (Mineralogical, sedimentological and palaeo-environmental study of Quaternary sediments from Ceglédbercel road cut, Hungary). Földtani Közlöny 142. (3): 269-286.

Kocsis, T., Kotroczó, Zs., Kardos, L. and Biró, B. 2020. Optimisation of increasing biochar doses with soil-plant-microbial functioning and nutrient uptake of maize. Environmental Technology \& Innovation 20. 101191.

Lin, H. 2012. Addressing fundamentals and building bridges to understand complex pedologic and hydrologic interactions. In Hydropedology: Synergistic Integration of Soil Science and Hydrology. Ed.: Lin, H., Cambridge MA, Elsevier, 3-39.

Lindbo, D.L., Stolt, M.H. and Vepraskas, M.J. 2010. Redoximorphic features. In Interpretation of Micromorphological Features of Soils and Regoliths. Eds.: Soops, G., Marcelino, V. and Mees, F., Cambridge MA, Elsevier, 129-147.

Martín-García, J.M., Sánchez-Marañón, M., Calero, J., Aranda, V., Delgado, G. and Delgado, R. 2016. Iron oxides and rare earth elements in the clay fractions of a soil chronosequence in southern Spain. European Journal of Soil Science 67. (6): 749-762.

Mills, S.J., Christy, A.G., Génin, J.-M.R., Kameda, T. and Соцомво, F. 2012. Nomenclature of the hydrotalcite supergroup: natural layered double hydroxides. Mineralogical Magazine 76. (5): 1289-1336.

Papp, O., Kocsis, T., Biró, B., Jung, T., Ganszky, D., Abod, É., TirczKa, I., Tóthné Bogdányi, F. and DREXLER, D. 2021. Co-inoculation of organic potato with fungi and bacteria at high disease severity of Rhizoctonia solani and Streptomyces spp. increases beneficial effects. Microorganisms 9-10. 16.

Rowel, D.L. 1994. Soil Science: Methods and Applications. London, Prentice Hall.

Samus, M.G., Comerio, M., Montes, M.L., Boff, L., Löffler, J., Mercader, R.C. and Bidegain, J.C. 2021. The origin of gley colors in hydromorphic vertisols: the study case of the coastal plain of the Río de la Plata estuary. Environmental Earth Sciences 80. (3): 1-15.

Schoeneberger, P.J., Wysocki, D.A., Benham, E.C. and Soil Survey Staff 2012. Field Book for Describing and Sampling Soils, Version 3.0. Natural Resources Conservation Service. Lincoln NE, National Soil Survey Center.

Schwertmann, U. 1993. Relations between iron oxides, soil color, and soil formation. In Soil Color 31. 51-69.

Sipos, P., Németh, T., May, Z. and Szalai, Z. 2011. Accumulation of trace elements in Fe-rich nodules in a neutral-slightly alkaline floodplain soil. Carpathian Journal of Earth and Environmental Sciences 6. (1): 13-22.
Sodano, M., Lerda, C., Nisticò, R., Martin, M., Magnacca, G., Celi, L. and Said-Pullicino, D. 2017. Dissolved organic carbon retention by coprecipitation during the oxidation of ferrous iron. Geoderma 307. 19-29.

Stoops, G., Marcelino, V. and Mees, F. 2010. Micromorphology as a tool in soil and regolith studies In Interpretation of Micromorphological Features of Soils and Regoliths. Eds.: Stoops, G., Marcelino, V. and Mees, F., Cambridge MA, Elsevier, 1-19.

SURÁNYI, D. 1965. A Gerje nagy áradásának krónikája (Chronicle of the great flooding on the Gerje). In Turini Százas Küldöttség Múzeumbaráti Kör Évkönyve, 1988. Ed.: Kocsis, Gr., Cegléd, Kossuth Múzeum, 144-154.

Szalai, Z., Jakab, G., Németh, T., Sipos, P., Mészáros, E., Di Gléria, M., Madarász, B., VARga, I. and Horváth-Szabó, K. 2010. Dynamics of organic carbon and dissolved iron in relation to landscape diversity. Hungarian Geographical Bulletin 59. (1): 17-33.

Szalai, Z., Szabó, M., Zboray, N., Kiss, K., HorváthSzabó, K., JaKab, G., Balázs, R., NÉMEth, T. and MADARász, B. 2012. Relationship between ecological indicators and soil properties (in case of a wetland). Hungarian Geographical Bulletin 61. (3): 187-196.

Szalai, Z., Ringer, M., Németh, T., Sipos, P., Perényi, K., PekKer, P., Balázs, R., VAncsik, A.V., Zacháry, D., Szabó, L., Filep, T., Varga Gy. and Jakab, G. 2021. Accelerated soil development due to seasonal water-saturation under hydric conditions. Geoderma 401. 115328.

Szendrei, G., Kovács-PÁlffy, P., Földvári, M. and GÁl-Sólymos, G. 2012. Mineralogical study of ferruginous and manganiferrous nodules separated from characteristic profiles of hydromorphic soils in Hungary. Carpathian Journal of Earth and Environmental Sciences 2012. 1.59-70.

TANGEN, B.A. and BANSAL, S. 2020. Soil organic carbon stocks and sequestration rates of inland, freshwater wetlands: Sources of variability and uncertainty. Science of the Total Environment 749. 141444.

Thompson, C.A., Bettis III, E.A. and BAKer, R.G. 1992. Geology of Iowa fens. Journal of the Iowa Academy of Science 99. (2-3): 53-59.

van Reeuwijk, L.P. 2002. Procedures for Soil Analysis. Rome, ISRIC-FAO. 